\title{
ANACARDIUM OCCIDENTALE LINN. (ANACARDIACEAE) STEM BARK EXTRACT INDUCES HYPOTENSIVE AND CARDIO-INHIBITORY EFFECTS IN EXPERIMENTAL ANIMAL MODELS
}

\author{
Francis Olivier Tchikaya ${ }^{1 *}$, Guy Bernard Bantsielé , Gisèle Kouakou-Siransy ${ }^{4}$, Jacques Yao Datté , Paul Angoue Yapo , \\ Noel Guedé Zirihi , Michel Atté Offoumou
}

Laboratoire de Nutrition et Pharmacologie, Département de Biologie Animale et Physiologie, UFR-Biosciences, Université de Cocody, Abidjan, Côte d'Ivoire, 20 BP 947 Abidjan 20, Côte d'Ivoire, 'Département de Physiologie Animale, Pharmacologie et Phytothérapie, UFR Science et Nature, Université d'Abobo-Adjamé, Abidjan Côte d'Ivoire, Département de Botanique, UFRBiosciences, Université de Cocody, 22 BP 582 Abidjan 22, Côte d'Ivoire., Laboratoire de Pharmacologie, Pharmacocinétique et Pharmacie Clinique, UFR Sciences Pharmaceutiques et Biologiques, Université de Cocody, 20 BP 947 Abidjan 20, Abidjan, Côte d'Ivoire.

* Email: ftchikaya@hotmail.com

\begin{abstract}
Anacardium occidentale Linn. (Anacardiaceae) is a plant largely used in Africa for the treatment of different diseases. In Côte d'Ivoire it's commonly used for the treatment of hypertension. The present study was carried out in order to assess the effects of Anacardium occidentale extract (ANOE) on cardiovascular parameters in animal models. A mercury manometer kymograph of Ludwig was used to measure the blood pressure of normotensive rabbits in control conditions (normal physiological solution) and under the influence of ANOE. The contractile activity of an isolated rat heart was also measured in control conditions and under the influence of ANOE in different physiological media using a modified Langendhorff (1895) apparatus. The aqueous Anacardium occidentale (ANOE) bark extract applied intravenously in different doses (12, 40, 90, and $167 \mathrm{mg} / \mathrm{kg} \mathrm{b.w.)}$, produced a significant dose-dependent decrease in blood pressure of previously normotensive rabbits (up to $89 \%$ vs control). Atropine $(1 \mathrm{mg} / \mathrm{ml})$ pre-treatment failed to reverse the hypotensive effects elicited by the extract. ANOE applied to isolated rat heart preparations in different concentrations $(0.01,0.1,1.0$, and $10 \mu \mathrm{g} / \mathrm{ml})$ induced negative inotropic and chronotropic effects. Atropine pre-treatment of heart preparations $(0.1 \mu \mathrm{g} / \mathrm{ml})$ failed to reverse the negative effects induced by ANOE. The extract's action on heart contractile activity studied in modified culture media further confirmed its cardio-inhibitory effects. ANOE induced strong hypotensive and cardio-inhibitory effects in animal models.
\end{abstract}

Key words: Anacardium occidentale Linn. (Cashew); Hypotension; Cardio-depression.

\section{Background}

In industrialized countries, hypertension affects over $20 \%$ of adult population, and is implicated in millions of deaths from stroke, heart failure and ischemic heart disease witnessed each year worldwide (Rosskopf et al, 2007). The World Health Organization has predicted that heart diseases and stroke shall gradually become even more deadly, with a projected combined death toll of 24 million by 2030 (Chumark et al, 2008; Sharma and Majumdar, 2009). In spite of the current low prevalence of hypertension in some countries, the total number of hypertensive subjects in the developing world is high. A cost analysis of possible antihypertensive drug treatments indicates that developing countries cannot afford the same treatment as the developed ones (Seedat, 2001). In sub-Saharan Africa, a region plagued by infectious and parasitic diseases, nutritional deficiencies and excessive maternal and perinatal morbidity and mortality, the prevention of cardiovascular diseases and risk factors is rarely on the public health agenda. The importance of herbal medicines in treating various ailments has already been established. There are potent indigenous herbal medicines available for certain diseases in various parts of the world, but many of them haven't been scientifically validated yet. Proper validation of such medicines could lead to the development of cost-effective drugs (Njoroge and Bussmann, 2006; Kitula, 2007; Suresh and Asha, 2008).

A plant falling into the family of Anacardiaceae, Anacardium occidentale Linn., originates from Brazil and was first introduced and cultivated in Africa for its cajou nuts; the various parts of the plant were then used in the pharmacopoeia to cure many diseases. Chemical investigations by Kossouoh et al. (2008) showed the presence of p-phellandren, limonene, methyl chavicol and germacren. Based on both haematological and histo-pathological examinations and biochemical analyses of renal and hepato-biliary functions (the level of urea, creatinine, transaminases and alkaline phosphatase), recent studies investigating into the toxicity of the Brazilian Cashew Tree leaves have concluded that hydroethanolic extract obtained from Anacardium Occidentale leaves, administered in doses of up to $2 \mathrm{~g} / \mathrm{kg}$ bw. (Konan and Bacchi, 2007; Konan et al, 2007) fails to produce toxic symptoms in rats and mice. Hexane extract obtained from Anacardium occidentale leaves was shown to have anti-hyperglycaemic and renal-protective effects in streptozotocin-induced diabetic rats, and to elicit no toxic effects in mice after an acute oral administration of extract doses lower than $6 \mathrm{~g} / \mathrm{kg}$ (Tédong et al, 2006; Tédong et al, 2007). The Cashew stem bark methanolic 
extract was also shown to exert anti-mutagenic and anti-genotoxic effects on Chinese hamster lung fibroblasts V79 (Barcelos et $\mathrm{al}, 2007 \mathrm{a}$ and b). Anacardium occidentale has been used in the treatment of urogenital infections (Adjanohoun et al, 1988), as well as an anti-diabetic agent (Kamtchouing et al, 1998); it has also been used to treat gastrointestinal disorders, mouth ulcers, throat problems (Kerharo and Adams, 1974; Kudi et a., 1999; Akinpelu, 2001; Gonçalves et al, 2005; Taylor, 2005), and hypertension. The current study was initiated in order to highlight possible hypotensive properties of Anacardium occidentale based on the effects of Anacardium occidentale extract (ANOE) established in various animal models.

\section{Materials and Methods Study design}

The aim of the study was to evaluate the effects of Anacardium occidentale extract (ANOE) on rabbit arterial blood pressure and rat heart contractility. Blood pressure of rabbits previously established as normotensive, was measured in the control conditions (i.e. in normal Mac-Ewen physiological solution) and under the influence of ANOE. Isolated rat heart contractile activity was also measured in the control conditions and under the influence of ANOE in different physiological media.

\section{Phytochemical screening}

The extract and its fractions were tested using Lieberman Bouchard, Ferric chloride, cyanidine stiasny, Valser-Meyer, and Dragendorff tests so as to determine the presence of sterols, phenolic compounds, flavonoids, tannin and alkaloids, respectively. The reagent used for Lieberman Bouchard test was anhydride acetic and sulphuric acid, employed to the goal of revealing sterol compounds. The extract was also tested using ferric chloride and cyanidine (droplets of isopentanol + magnesium) so as to reveal the presence of polyphenols and flavonoids, respectively. Tannin was uncovered using the Stiasny reagent, while the presence of alkaloids was unmasked using Valser-Meyer and Dragendorff tests.

\section{Plant material}

Anacardium occidentale Linn stem barks were collected in October 2004 in the Department of Tanda (region of Zanzan, East of Côte d'Ivoire). The collected barks were given to the botanic expert Prof Aké-Assi Laurent affiliated with the University of Cocody (Abidjan), who verified their uniformity with the specimens previously deposited and catalogued in the herbarium of the "Centre National Floristique" at the University of Cocody (voucher number 14649).

\section{Preparation of Anacardium occidentale Linn extract}

The collected bark pieces were dried at the room temperature $\left(27 \pm 3^{\circ} \mathrm{C}\right)$. Powdered bark $(50 \mathrm{~g})$ was first macerated for 24 hours in $250 \mathrm{ml}$ of $n$-hexane to remove chlorophyll and other hexane-soluble substances. The residue was dried and extracted by means of vigorous shaking in bi-distilled water for 24 hours. After a $2 \mathrm{~h}$-extraction and filtration, the filtrate was concentrated by means of solvent evaporation using a Rotavapor of the BUCCHI type. The drug (ANOE) obtained was stored at $4^{\circ} \mathrm{C}$ until use.

\section{Animals}

All animals were purchased from Faci Experimental Animal Co (Abidjan, Côte d'Ivoire). The animals were then bred at the Department of Nutrition and Pharmacology of the University of Cocody. Normotensive, 12 to 20 week-old rabbits (Oryctolagus cuniculus) weighing 1.6-2 kg and 8 to 12 week-old Wistar rats (weighing 195-250g) of both sexes were used for the experiments. The rabbits were housed in individual cages at constant humidity $(60 \%)$ and the temperature of $22-25^{\circ} \mathrm{C}$ with alternating 12-hour light/dark cycles, and left to acclimatize to these conditions for a week. The rats were housed in cages of four. The animals were anesthetized with ethyl urethane; during the experiments, all animals were allowed to breathe spontaneously. The rabbits were used to record the arterial blood pressure and the rats served the purpose of recording an isolated heart contractile activity. The animals were cared for and treated according to the principles of care for, and use of, laboratory animals, formally approved by the Board of Ethics of the Cocody University, in compliance with the Guide for Care and Use of Laboratory Animals observed by the Institute for Laboratory Animal Research.

\section{Direct arterial blood pressure measurements completed in the rabbits}

The animals were conditioned by being deprived of food 24 hours prior to the experiments; they were then anesthetized via the marginal ear vein using $40 \%$-ethyl urethane solution in the dose of $2.5 \mathrm{ml} / \mathrm{kg} \mathrm{b}$.w. and placed in dorsal recumbent position. The rabbits' saphena vein and carotid artery were isolated, catheterized and heparinized using Mac-Ewen heparin solution. The carotid artery was catheterized and connected to a mercury manometer kymograph of Ludwig. After recording the animals' normal blood pressure, ANOE was injected via the saphena vein in form of $0.5 \mathrm{ml}$-boluses at eight different increasing doses so as to obtain a dose-response curve. The doses $(0.83,11,28,50,77$, and $111 \mathrm{mg} / \mathrm{kg}$ b.w.) were injected at 5 minute-intervals up to the cumulative doses of $0.83,12,40,90,167$, and $279 \mathrm{mg} / \mathrm{kg} \mathrm{b.w}$. The resulting blood pressure variations were transmitted to the mercury manometer and recorded by stylet on a carbon paper that scrolled at the speed of $1 \mathrm{~mm} / \mathrm{sec}$. Mean arterial blood pressure 
(MABP) values were derived from the pool of 5 experiments $(n=5)$. To study the effects of ANOE in the presence of atropine, the animals were pre-treated accordingly. Two minutes after the pre-treatment, some of the animals were injected with ANOE, while the others were injected with ANOE prior to being injected with atropine.

\section{Tissue preparation and recording of cardiac muscle contractile activity}

Wistar rats were anaesthetized using 20\%-ethyl urethane in the intra-peritoneal dose of $5 \mathrm{ml} / \mathrm{kg}$ b.w. and placed in dorsal recumbent position. The animals' chests were opened; the aorta was cleaned from any adherent fat and connective tissue and then catheterized using a catheter that contained Mac-Ewen physiological solution. The heart was then removed and connected to a modified Langendhorff (1895) apparatus for heart activity recording. The contractile activity of the heart [contractile force $(\mathrm{CF})$ and heart rate $(\mathrm{HR})$ ] was monitored until stabilisation. After normal activity recording $(\mathrm{n}=10)$, various concentrations of ANOE $(0.01 \mu \mathrm{g} / \mathrm{ml}, 0.1 \mu \mathrm{g} / \mathrm{ml}, 1 \mu \mathrm{g} / \mathrm{ml}$ and $10 \mu \mathrm{g} / \mathrm{ml}$ in Mac-Ewen physiological solution) were tested along with other drugs or substances. Changes in heart contractile activity were recorded on a carbon paper that scrolled at the rate of 2 $\mathrm{mm} / \mathrm{s}$. Cardiac contractile force (amplitude) was measured by virtue of averaging the height of five carbon paper recordings obtained during each experiment, while the heart rate (frequency) was measured by means of counting the pikes (heart cycles) per minute recorded during each experiment.

\section{Chemicals}

The composition of Mac-Ewen physiological solution (given in $\mathrm{mM}$ ) was as follows: $\mathrm{NaCl} 130 ; \mathrm{KCl} 2.50 ; \mathrm{CaCl}_{2} 2.40$; $\mathrm{Na}_{2} \mathrm{H}_{2} \mathrm{PO}_{3}$ 1.18; $\mathrm{Na}_{2} \mathrm{CO}_{3} \mathrm{H} 11.90 ; \mathrm{MgCl}_{2} 0.24$ and glucose 2.2; $\mathrm{pH}=7.4$; it was bubbled with a gas mixture of $95 \%$ of $\mathrm{O}_{2}$ and $5 \%$ of $\mathrm{CO}_{2}$, and maintained at $37^{\circ} \pm 1^{\circ} \mathrm{C}$. To better understand the action of ANOE on cardiac activity, we studied its effects within modified ionic media. These modified media had the same composition as the normal Mac-Ewen solution detailed above (control, $100 \%$ ), except for the concentration of specific ions which was either increased or decreased so as to equal to the following: calcium-depleted medium (Ca $75 \%$ ) contained $1.8 \mathrm{mM}_{\text {of }} \mathrm{CaCl}_{2}$ instead of 2.4 , calcium-enriched medium (Ca $\left.125 \%\right)$ contained 3 $\mathrm{mM}$ of $\mathrm{CaCl}_{2}$ instead of 2.4 , potassium-depleted medium (K $50 \%$ ) contained $1.25 \mathrm{mM}$ of KCl instead of 2.5 and sodium-depleted medium $(\mathrm{Na} 50 \%)$ contained $65 \mathrm{mM}$ of $\mathrm{NaCl}$ instead of 130 . The iso-osmolarity of the modified media was maintained by virtue of saccharin (sucrose) addition (Molnár et al, 2003). Atropine was purchased from Sigma-Aldrich Co. (St. Louis, MO, USA).

\section{Statistical analysis}

All values are expressed as means \pm SEM. Statistical evaluation of the data was performed using Student's $t$-test. Data were compared using Student's t-test or one-way ANOVA followed by Bonferroni test where suitable. P values of $<0.05$ were considered indicative of significant differences.

\section{Results \\ Phytochemical screening results}

The phytochemical study showed Anacardium occidentale extract to be rich in polyterpenes and phenolic compounds (phenols, lignans and flavonoids). Sterols and tannins were found in ANOE as well.

\section{The effects of ANOE on arterial blood pressure}

Blood pressure of the anesthetized rabbits was recorded in absence (the control) and presence of ANOE. In the control experiments ( $\mathrm{n}=5$ experiments), MABP was constant and not influenced by the vehicle (Mac-Ewen physiological salt solution, original tracing not shown). MABP recorded in the rabbits was $73 \pm 1.55 \mathrm{~mm} \mathrm{Hg}$. Intravenous ANOE injections in doses ranging from $12 \mathrm{mg} / \mathrm{kg}$ b.w. to $167 \mathrm{mg} / \mathrm{kg}$ b.w. were found to be active and caused a significant and ever more marked tension drop. As shown in Figure 1, MABP went from $70.8 \pm 2.2 \mathrm{mmHg}$ at $12 \mathrm{mg} / \mathrm{kg}$ b.w. ( $\mathrm{p}=0.188$, which represents a tension drop of $3 \%$ vs control) to $8 \pm 0.8 \mathrm{mmHg}$ at $167 \mathrm{mg} / \mathrm{kg}$ b.w. $(P<0.001$, which represents a tension drop of $89 \%$ vs control). The dose of 279 $\mathrm{mg} / \mathrm{kg}$ b.w. was lethal since it led to the vascular collapse.

\section{The effects of ANOE seen on MABP in the presence of atropine}

In order to find out more about the mode of action of ANOE, the animals were treated with atropine $(0.5 \mathrm{and} 1 \mathrm{mg} / \mathrm{ml})$. In these experiments, a single extract dose was used every time and produced the effect that lasted over an hour. The experiment was repeated in another group of animals, but the latter received the extract either 2 minutes after or 2 minutes prior to atropine administration. These experiments were conducted with two ANOE doses ( 40 and $90 \mathrm{mg} / \mathrm{kg} \mathrm{b.w.).} \mathrm{The} \mathrm{study} \mathrm{conducted} \mathrm{with} \mathrm{the}$ highest atropine concentration $(1 \mathrm{mg} / \mathrm{ml}$ ) gave the following results: $\mathrm{MABP}=76 \pm 1.2 \mathrm{mmHg}$ (control, $\mathrm{n}=3$ ), $\mathrm{MABP}=75 \pm 2.3$ $\mathrm{mmHg}$ (after atropine injection) and MABP $=66 \pm 3 \mathrm{mmHg}$ (after $40 \mathrm{mg} / \mathrm{kg}$ b.w. ANOE injection; $P<0.05 \mathrm{vs}$ control). The reverse situation yielded the following results: $\mathrm{MABP}=74 \pm 2.1 \mathrm{mmHg}$ (control, $\mathrm{n}=3), \mathrm{MABP}=62 \pm 3.3 \mathrm{mmHg}(\mathrm{after} 40 \mathrm{mg} / \mathrm{kg}$ b.w. ANOE injection; $P<0.05 \mathrm{vs}$ control) and MABP $=61 \pm 1.1 \mathrm{mmHg}$ (after atropine injection). The second series of tests gave 
the following results: $\mathrm{MABP}=72 \pm 1.4 \mathrm{mmHg}$ (control, $\mathrm{n}=3$ ), $\mathrm{MABP}=71 \pm 1.7 \mathrm{mmHg}$ (after, $1 \mathrm{mg} / \mathrm{ml}$ atropine injection) and $\mathrm{MABP}=16 \pm 1.3 \mathrm{mmHg}$ (after $90 \mathrm{mg} / \mathrm{kg}$ b.w. ANOE injection; $P<0.001 \mathrm{vs}$ control). The reverse situation yielded the following results: $\mathrm{MABP}=73 \pm 2.1 \mathrm{mmHg}$ (control, $\mathrm{n}=3$ ), $\mathrm{MABP}=17 \pm 1.8 \mathrm{mmHg}$ (after $90 \mathrm{mg} / \mathrm{kg}$ b.w. ANOE injection; $P<0.001 \mathrm{vs}$ control) and MABP $=16 \pm 1.1 \mathrm{mmHg}$ (after atropine injection). In both cases, atropine failed to reverse the hypotensive effects induced by ANOE.

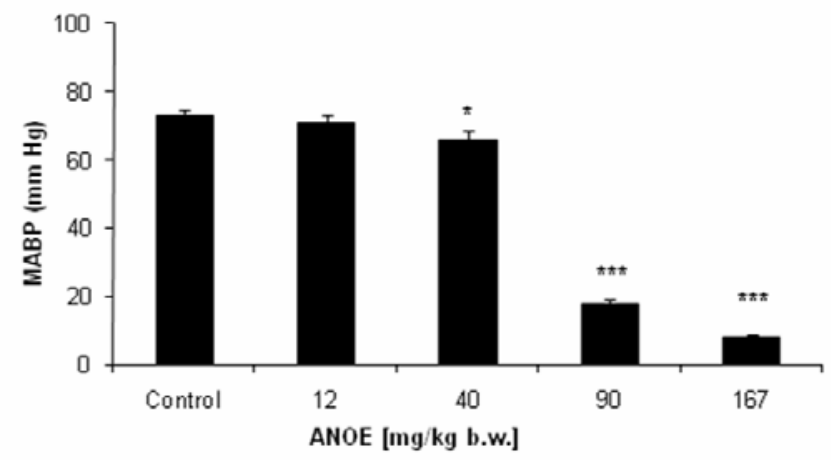

Figure 1: The effects of ANOE on the rabbits' arterial blood pressure.

ANOE was injected to the animals in doses ranging from $12 \mathrm{mg} / \mathrm{kg}$ b.w. to $167 \mathrm{mg} / \mathrm{kg}$ b.w.. The control represents the blood pressure recorded in normotensive animals before ANOE injection. The injection of each ANOE concentration elicited MAPB decrease. Ordinate: Response expressed in millimetres Hg. Abscissa: ANOE doses. Data are expressed as means $\pm \operatorname{SEM}(n=5)$. *, $p<0.05$ vs. control; **, $P<0.01$ vs. control; ***, $P<0.001$ vs. control.

\section{The effects of ANOE on the cardiac contractile activity}

Mechanical activity of an isolated heart results in contractions of either average or variable amplitudes, depending on the functional state of the preparation. To determine the mechanisms underlying the inhibitory effects of ANOE exhibited on MABP, experiments aiming to investigate the contractile activity of an isolated cardiac muscle in the presence of ANOE were carried out. The super-fusion of the heart with increasing concentrations of ANOE resulted in the fugacious increase in contractile force (CF; positive inotropic effect), followed by the concentration-dependent reduction in both heart rate (HR) and CF (negative chronotropic and inotropic effects). Negative effects of ANOE on the contractile activity of the heart were bluntly obvious with doses ranging from $0.01 \mu \mathrm{g} / \mathrm{ml}$ to $10 \mu \mathrm{g} / \mathrm{ml}$. These ANOE concentrations produced fully and quickly reversible effects $(\mathrm{n}=10)$. With higher ANOE concentrations, the effects were not reversible so easily. The results are expressed as percentages of CF and HR reductions vs. control (fixed at $100 \%$ - activity).

ANOE concentrations tested were as follows: $0.01,0.1,1.0$, and $10 \mu \mathrm{g} / \mathrm{ml}$. As opposed to $100 \%$-control activity, ANOE concentrations quoted above elicited the following responses: $88 \%-, 90 \%-, 85 \%$ - and $75 \%$ - CF reduction; and 79\%-, 72\%-, 69\%and $67 \%$ - HR reduction. Each of these $\mathrm{CF}$ and HR reductions was significant as compared to the control $(P<0.001$, Student's t test, $\mathrm{n}=10)$. Figure 2 represents $\mathrm{CF}$ and HR variations seen in the presence of increasing ANOE concentrations.

\section{The effects of ANOE on the cardiac contractile activity seen in the presence of atropine}

The effects of ANOE on the cardiac contractile activity were studied in the presence of atropine, a muscarinic cholinoceptor antagonist. When super-fused with normal Mac-Ewen physiological solution (control) the heart exhibited the following characteristics: $\mathrm{CF}=29 \pm 3 \mathrm{~mm}$ and $\mathrm{HR}=184 \pm 5 \mathrm{C} / \mathrm{min}$. Following a 2 minute-atropine treatment, both $\mathrm{CF}$ and $\mathrm{HR}$ remained unchanged. After the heart super-fusion using ANOE $(0.1 \mu \mathrm{g} / \mathrm{ml})$, both CF and HR dropped down to $16 \pm 2 \mathrm{~mm}(44.8 \%$ decrease) and $136 \pm 3 \mathrm{C} / \mathrm{min}(26 \%$-decrease), respectively $(\mathrm{n}=3 ; P<0.001)$. For the sake of comparison, heart characteristics registered in the control conditions were as follows: $\mathrm{CF}=25 \pm 1.7 \mathrm{~mm}, \mathrm{HR}=180 \pm 5 \mathrm{C} / \mathrm{min}$. ANOE addition $(0.1 \mu \mathrm{g} / \mathrm{ml}) \mathrm{decreased}$ both CF and HR to $20 \pm 1.3 \mathrm{~mm}$ and $153 \pm 6 \mathrm{C} / \mathrm{min}$, respectively (i.e. by $20 \%$ and $15 \%$, respectively) $(P<0.01)$. Two minuteatropine heart super-fusion $(0.1 \mu \mathrm{g} / \mathrm{ml})$ brought $\mathrm{CF}$ up to $20 \pm 3 \mathrm{~mm}$, while HR dropped down to $138 \pm 3 \mathrm{C} / \mathrm{min}$, which represents a $23 \%$-decrease as compared to the control $(\mathrm{n}=3 ; \mathrm{P}<0.001)$.

\section{The effects of ANOE on the cardiac contractile activity seen in modified physiological media}

In all of the experiments elaborated under this section, ANOE was used at the concentration of $0.1 \mu \mathrm{g} / \mathrm{ml}$. The experiments were carried out as follows: recording of the heart contractile activity in normal Mac-Ewen physiological solution (control) followed by the recording of the cardiac activity in a modified medium and subsequent recording of the cardiac activity in a modified medium combined with ANOE. The heart was then washed with normal Mac-Ewen physiological solution $(\mathrm{n}=15)$. 


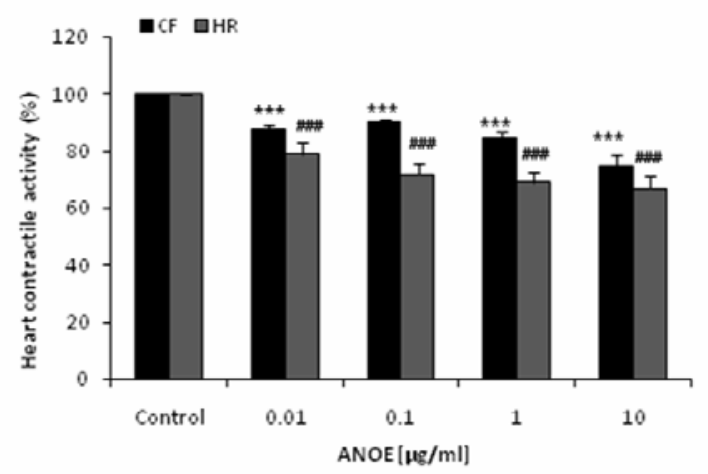

Figure 2: The effects of ANOE on an isolated rat heart contractile activity.

Isolated rat hearts were super-fused with Mac-Ewen physiological solution containing ANOE at the concentrations ranging from $0.01 \mu \mathrm{g} / \mathrm{ml}$ to $10 \mu \mathrm{g} / \mathrm{ml}$. The addition of each concentration elicited a decrease in heart contractile activity. The control represents the contractile force (CF) and heart rate (HR) recorded before heart super-fusion with ANOE (values were normalized and fixed at $100 \%)$. Ordinate: responses expressed in percentages. Abscissa: ANOE concentrations. Data are expressed as means $\pm \operatorname{SEM}(n$ $=10) ;{ }^{* * *}, P<0.001$ vs. control for CF; \#\#, $P<0.001$ vs. control for heart rate.

The effects of ANOE on the cardiac contractile activity seen in calcium-depleted medium (Ca 75\%)

The control recording (obtained with normal physiological solution) revealed the CF of $25 \pm 2.85 \mathrm{~mm}$ and the HR of $180 \pm 3 \mathrm{C} / \mathrm{min}$. With Ca $75 \%$, HR increased by $43 \%$ after $2 \min (P<0.01$ vs control) of super-fusion, while CF decreased by $16 \%$. In Ca $75 \%$ containing ANOE, HR increased by $103 \%(P<0.001$ vs control), while CF dropped down by $36 \%(P<0.01$ vs control) as compared to in the values obtained with normal physiological solution (Figure 3A). The comparison between heart activity seen with $\mathrm{Ca} 75 \%$ and $\mathrm{Ca} 75 \%$ containing ANOE showed that ANOE supplementation led to the CF drop of $24 \%$ ( $P<$ 0.05 , Student's $t$ test, $n=15)$ and the HR increase of $42 \%(P<0.001$, Student's $t$ test, $n=15)$.

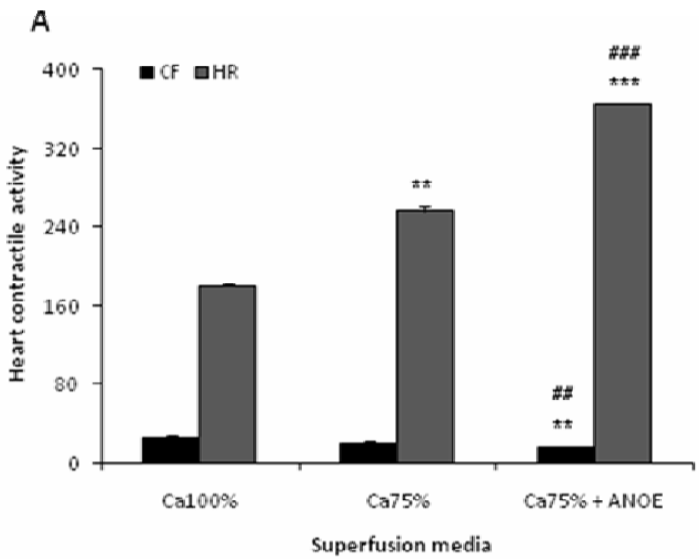

Figure 3A: The effects of ANOE on the heart contractile activity in Ca-depleted medium.

The control (Ca 100\%) represents the contractile force (CF) and heart rate (HR) of the heart recorded in normal Mac-Ewen physiological solution. In this experiment ANOE was used in the single concentration of $0.1 \mu \mathrm{g} / \mathrm{ml}$. Ordinate: CF is expressed in millimetres, while HR is given as the number of contractions/minute. Abscissa: super-fusion media. Data are expressed as means $\pm \operatorname{SEM}(n=15)$. In calcium-depleted medium, for CF: **, $P<0.01$ for Ca $75 \%+$ ANOE vs. control; and $\#, p<0.05$ for Ca $75 \%$ vs Ca $5 \%+$ ANOE. For HR: **, $P<0.01$ for Ca $75 \%$ vs control, $* * *, P<0.001$ for Ca $75 \%+$ ANOE vs. control, and \#\#\#,?? $P<$ 0.001 for $\mathrm{Ca} 75 \%$ vs $\mathrm{Ca} 75 \%$ + ANOE. In calcium-enriched medium, for HR: $* * *, P<0.01$ for $\mathrm{Ca} 125 \%$ and $\mathrm{Ca} 125 \%+\mathrm{ANOE}$ vs control, and \#\#??, $P<0.001$ for Ca $125 \%$ vs Ca $125 \%$ + ANOE.

The effects of ANOE on the cardiac contractile activity seen in calcium-enriched medium (Ca 125\%)

The control recording revealed the $\mathrm{CF}$ of $37 \pm 4.5 \mathrm{~mm}$ and the $\mathrm{HR}$ of $182 \pm 6 \mathrm{C} / \mathrm{min}$. With $\mathrm{Ca} 125 \%, \mathrm{CF}$ and $\mathrm{HR}$ increased by $22 \%(\mathrm{P}=0.06)$ and $54 \%$, respectively $(P<0.001$ vs control). In $\mathrm{Ca} 125 \%$ containing ANOE, $\mathrm{CF}$ and HR dropped down by $18 \%(\mathrm{P}=0.06)$ and $22 \%$, respectively $(P<0.001 \mathrm{vs}$ control), as compared to the preceding increase (Figure $3 \mathrm{~B})$. 


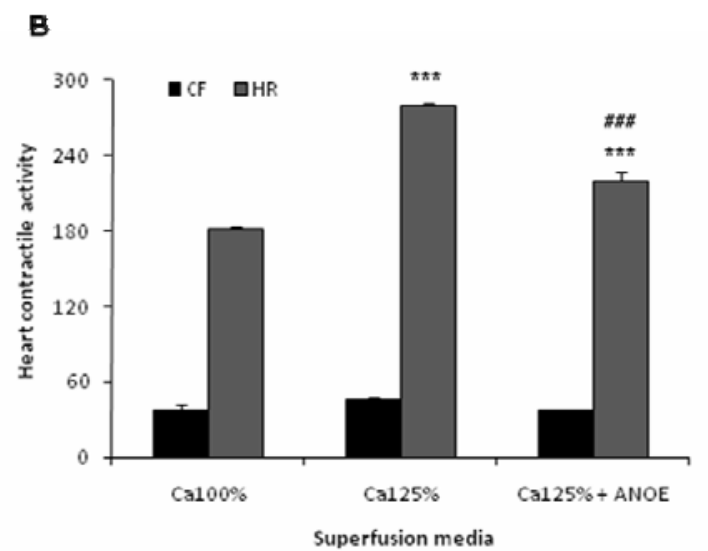

Figure 3B: The effects of ANOE on the heart contractile activity in Ca-enriched medium.

The effects of ANOE on the contractile activity of the heart seen in sodium-depleted medium (Na 50\%)

The control recording revealed the $\mathrm{CF}$ of $35 \pm 3.14 \mathrm{~mm}$ and the $\mathrm{HR}$ of $182 \pm 2.44 \mathrm{c} / \mathrm{min}$. After a transient increase, CF measured in Na 50\% dropped down in a drastic manner before stabilizing at $13 \pm 1.31 \mathrm{~mm}$ (which represents a $63 \%$-drop, $P<$ 0.001 vs control), while HR increased considerably to reach $493 \pm 2.63 \mathrm{c} / \mathrm{min}$ (which represents a $271 \%$-increase, $P<0.001$ vs control). With Na 50\% containing ANOE, CF kept dropping down, while after a substantial increase HR also dropped down in a quick and steep manner; both parameters were eventually brought down to the cardiac arrest level (Figure 4).

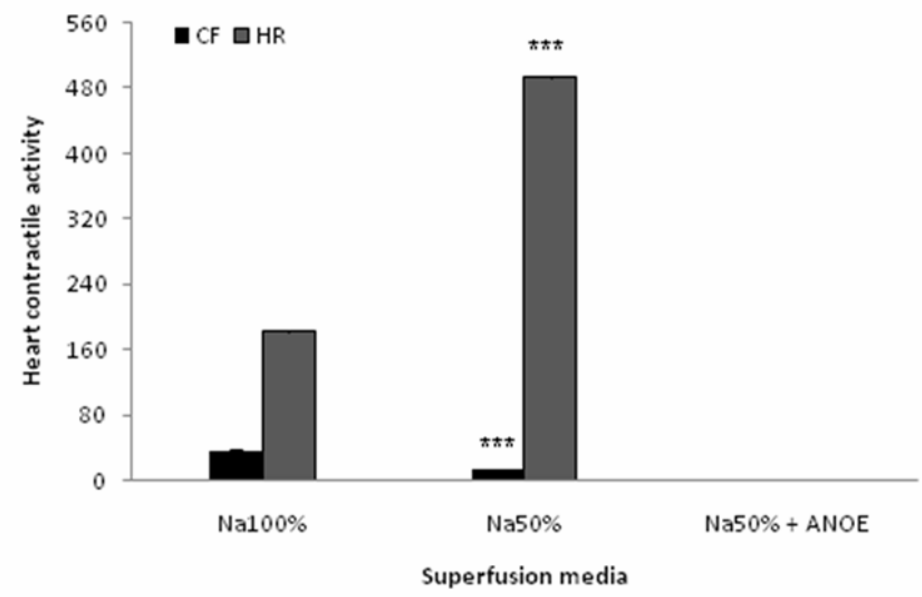

Figure 4: The effects of ANOE on the heart contractile activity in Na-depleted medium.

The control (Na 100\%) represents the contractile force (CF) and heart rate (HR) recorded in normal Mac-Ewen physiological solution. In this experiment ANOE was used in the single concentration of $0.1 \mu \mathrm{g} / \mathrm{ml}$. Ordinate: CF is expressed in millimetres, while HR is expressed as the number of contractions/minute. Abscissa: super-fusion media. Data are expressed as means $\pm \mathrm{SEM}$ $(n=15)$. ${ }^{* *}, P<0.001$ vs. control for both $\mathrm{CF}$ and HR.

The effects of ANOE on the cardiac contractile activity in potassium-depleted medium (K 50\%)

The control recording revealed the $\mathrm{CF}$ of $30 \pm 2.9 \mathrm{~mm}$ and the $\mathrm{HR}$ of $186 \pm 1.6 \mathrm{c} / \mathrm{min}$. With $\mathrm{K} 50 \%, \mathrm{CF}$ and $\mathrm{HR}$ increased by $30 \%$ ( $P<0.01$ vs control) and $106 \%$, respectively $(P<0.001$ vs control). With K $50 \%$ containing ANOE, CF and HR dropped down by $36 \%$ and $37 \%$, respectively, as compared to the preceding increase $(P<0.001)$ (Figure 5). 


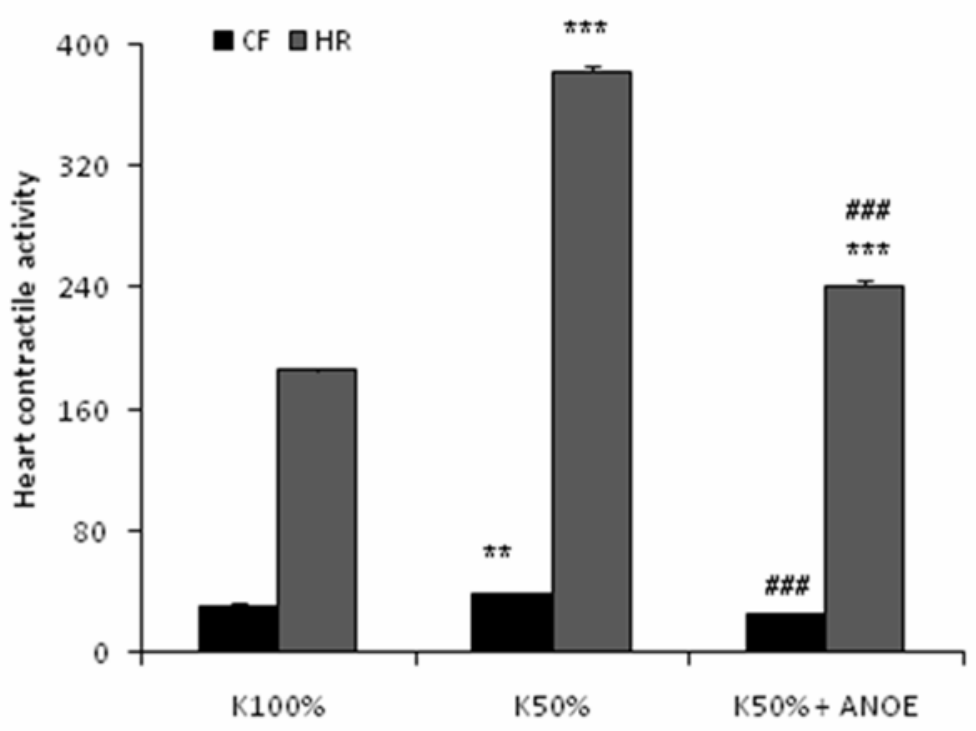

Superfusion media

Figure 5: The effects of ANOE on the heart contractile activity in K-depleted medium.

The control (K 100\%) represents the contractile force (CF) and heart rate (HR) recorded in normal Mac-Ewen physiological solution. In this experiment ANOE was used in the single concentration of $0.1 \mu \mathrm{g} / \mathrm{ml}$. Ordinate: CF is expressed in millimetres, while HR is given as the number of contractions/minute. Abscissa: super-fusion media. Data are expressed as means \pm SEM $(n=15)$. For CF: $* *, P<0.01$ for K 50\% vs control; and \#\#\#, $p<0.001$ for K 50\% vs K50\% + ANOE. For HR: $* * *, P<0.001$ for K $50 \%$ and $\mathrm{K} 50 \%+$ ANOE vs control; and \#\#\#, $P<0.001$ for K $50 \%$ vs K $50 \%+$ ANOE

\section{Discussion}

The overall objective of this study was to determine whether the traditional use of Anacardium occidentale in hypertension treatment is based on actual pharmacological effects of the plant that could be demonstrated in animals and, if so, to try to understand the mode of action of this plant using the tools at our disposal. Our results showed that ANOE exerts a concentration-related hypotensive effect on rabbits' arterial blood pressure. With doses ranging from 40 to $167 \mathrm{mg} / \mathrm{kg}$ b.w., this hypotension can be described as striking. The development of this hypotension showed that ANOE could have either a direct inhibiting effect on the cardiac activity or a vasodilating effect on vascular muscles. These effects might be coupled or associated with the influence of ANOE on the central nervous system (Cooper, 2001; Wang and Wang, 2007). ANOE's effects on animals in vivo were acetylcholine-like; the latter are known to be mediated by five receptors (M1-M5). Muscarinic acetylcholine receptors are involved into the regulation of many fundamental central and peripheral functions (Levine et al, 1999 and 2001). Besides M2 subtype widely present in mammalian hearts, some studies showed the presence of M1 subtype in rat heart and gave a strong indication of co-existence of functional M2 and M3 subtypes in rabbit heart (Kan et al, 1996; Wang et al, 2004). A recent study done in mice lacking M2 and M3 subtypes, clearly showed the important role of M2 (not M1 or M3) receptors in regulating heart contractile activity in vivo, while M3 subtype had a more significant role in peripheral regulation, thus controlling the modifications in blood pressure (Fisher et al, 2004). Since atropine failed to prevent the development of ANOE effects in vivo, it is reasonable to assume that ANOE did not act via M2 and M3 muscarinic receptor subtypes.

The action of ANOE on an isolated rat heart resulted in a transient positive inotropic effect followed by negative chronotropic and inotropic effects. This result led us to suggest that ANOE might contain both cardio-activating and cardioinhibitory components, the effects of the latter components being seemingly stronger or more prominent. It is known that acetylcholine inhibits heart activity by decreasing the auricular contractile force (Prokopczuk et al, 1981; Groschner et al, 1986). Acetylcholine challenges muscarinic receptors within the heart (Webb and Hollander, 1956), whose activation induces negative inotropic effects akin to those of ANOE. The fact that atropine failed to prevent the development of ANOE-induced heart effects suggests that ANOE does not act via M1 and M2 muscarinic receptor subtypes.

Cardiac activity is normally regulated by a certain number of ion flows (Langer, 1965). Lüttgau and Niedergerke (1958) showed the cardiac activity to be dependent on extra-cellular ionic conditions. Studies of ANOE effects in modified physiological media were thus necessary to better understand the specific mode of action of this plant. It was shown by Verrijk et al. (1990) that 
calcium-enriched medium will support an increase in the cardiac contractile force, whereas a calcium-depleted medium will diminish that force. At $0.1 \mu \mathrm{g} / \mathrm{ml}$, ANOE, which normally induces a major reduction in both contractile force and heart rate, induced moderate negative inotropic and chronotropic effects in calcium-enriched medium. In contrast, negative inotropic and positive chronotropic effects obtained in calcium-depleted medium, were potentiated by ANOE. It thus seems that ANOE behaves like a calcium channel antagonist (Kohlhardt et al, 1978; Romero et al, 2003); it could act either through calcium channels' blockage which would prevent calcium from entering into cells (Fleckenstein, 1981 and 1983) or through the hindrance of calcium release from its internal storages, as seemingly suggested by the results obtained with calcium-depleted medium. Thus the two effects combined could give an account for cardio-depression.

While examining the effects of internal and external ions on calcium ion flow in mammalian cardiac muscle, Glitsh et al (1970) showed that the decrease in extra-cellular sodium ion concentration increases calcium influx, whereas the increase in extra-cellular sodium ion concentration decreases it. It is actually known that there exists a competition between these two ions which tend to pass through the same $\mathrm{Na}-\mathrm{Ca}$ exchange channel. This could explain the temporary increase in cardiac contractile force seen in sodium-depleted medium prior to its eventual decrease. In sodium-depleted medium containing ANOE, this decrease in contractile force is even more prominent. The inhibiting action of ANOE seen in sodium-depleted medium would go in favour of the reduction in calcium influx attained via $\mathrm{Na}-\mathrm{Ca}$ exchange channel inhibition, this channel thereby being responsible for the transition of calcium through the cell membrane (Wettwer and Ravens, 1991).

In potassium-depleted medium, positive inotropic and chronotropic effects were observed. Eisner and Lederer (1979a and b), who worked with mammalian ventricular fibres, reported about the blockage of $\mathrm{Na}+\mathrm{K}+$ pump induced by a hypopotassic medium, leading to the intracellular impoverishment in potassium ions and fall in potassic conductance. The inhibition of $\mathrm{Na}+/ \mathrm{K}+$ pump could cause an impoverishment in extracellular sodium ions (Laughlin, 2001; Scheiner-Bobis, 2002; Faller, 2008), which would go in favour of an increase in calcium influx triggered by setting $\mathrm{Na}+/ \mathrm{Ca}++$ exchange mechanism in motion. Lepeschkin et al (1957) reported that, owing to the prolongation of the cardiac action potential plateau underpinned by the sustained calcium influx, a medium poor in potassium ions delays the repolarisation phase of the heart cycle causing the intracellular accumulation of calcium ions responsible for the positive inotropic effect observed by the authors. The reduction in heart contractile force confirms the assumption that ANOE works as a calcium channel antagonist. Thus ANOE probably also inhibits the release of intracellular calcium causing cardio-depression, the paramount role of calcium ions in contractile activity of muscular structures thereby being well-known (Katz et al, 1966; Domeier et al, 2008; Shenkman and Nemirovskaia, 2009; Piétri-Rouxel et al, 2010).

\section{Conclusion}

The bark stem extract of Anacardium occidentale showed hypotensive activities in vivo and cardio-inhibitory activities in vitro. In the modern world being under massive attack of cardiovascular diseases (CVDs) that pose as one of the greatest threats to humanity, these results can be exploited for further research in order to eventually come up with a natural cure for hypertension and CVD. Therefore, further physiological and pharmacological investigations both in vivo and in vitro will surely improve our knowledge of natural substances used to treat hypertension, especially that of Anacardium occidentale which displays characteristics justifying its use in traditional medicine.

\section{Acknowledgements}

The authors are thankful to Professor Laurent Aké Assi for his expert assistance in botanical identification of the plant material used in the study.

\section{References}

1. Adjanohoun, E.J., Ahyi, M.R.A., Ake Assi, L., Baniakina, J., Chibon, P., Cusset, G., Doulou, V., Enzanza, A., Eyme, J., Goudote, E., Keita, A., Mbemba, C., Mollet, J., Moutsambote, J.M., Mpati, J. and Sita, P. (1988). Contribution aux études ethnobotaniques et floristiques en République populaire du Congo. A.C.C.T.; ISBN92-9028-123-5, 605pages.

2. Akinpelu, D.A. (2001). Antimicrobial activity of Anacardium occidentale bark. Fitoterapia, 72:286-7.

3. Barcelos, G.R., Shimabukuro, F., Mori, M.P., Maciel, M.A. and Cólus, I.M. (2007a). Evaluation of mutagenicity and antimutagenicity of cashew stem bark methanolic extract in vitro. J. Ethnopharmacol., 114:268-73.

4. Barcelos, G.R., Shimabukuro, F., Maciel, M.A. and Cólus, I.M. (2007b). Genotoxicity and antigenotoxicity of cashew (Anacardium occidentale L.) in V79 cells. Toxicol. In Vitro, 21:1468-75.

5. Chumark, P., Khunawat, P., Sanvarinda, Y., Phornchirasilp, S., Morales, N.P., Phivthong-Ngam, L., Ratanachamnong, P., Srisawat, S. and Pongrapeeporn, K.U. (2008). The in vitro and ex vivo antioxidant properties, hypolipidaemic and antiatherosclerotic activities of water extract of Moringa oleifera Lam. leaves. J. Ethnopharmacol., 116: 439-46.

6. Cooper, E. (2001). Nicotinic acetylcholine receptors on vagal afferent neurons. Ann. NY Acad. Sci., 940:110-8.

7. Domeier, T.L., Zima, A.V., Maxwell, J.T., Huke, S., Mignery, G.A. and Blatter, L.A. (2008). IP3 receptor-dependent Ca2+ release modulates excitation-contraction coupling in rabbit ventricular myocytes. Am. J. Physiol. Heart Circ. Physiol., 294:H596-604. 
8. Eisner, D.A. and Lederer, W.J. (1979a). Inotropic and arrhythmogenic effects of potassium-depleted solutions on mammalian cardiac muscle. J. Physiol., 294:255-77.

9. Eisner, D.A. and Lederer, W.J. (1979b). The role of the sodium pump in the effects of potassium-depleted solutions on mammalian cardiac muscle. J. Physiol., 294:279-301.

10. Faller, L.D. (2008). Mechanistic studies of sodium pump. Arch. Biochem. Biophys., 476 :12-21.

11. Fisher, J.T., Vincent, S.G., Gomeza, J., Yamada, M. and Wess, J. (2004). Loss of vagally mediated bradycardia and bronchoconstriction in mice lacking M2 or M3 muscarinic acetylcholine receptors. FASEB J, 18:711-3.

12. Fleckenstein, A. (1981). Fundamental action of calcium antagonists on myocardial and cardiac pacemaker cell membranes. In: Weiss GB, Ed. New. Perspectives on calcium antagonists. Baltimore.

13. Fleckenstein, A. (1983). Calcium antagonism in heart and smooth muscle. New York: John Wiley and Sons.

14. Glitsch, H.G., Reuter, H. and Cholz, H. (1970). Effect of the internal sodium concentration on calcium fluxes in isolated guinea pig auricles. J. Physiol. London, 209: 25-43.

15. Gonçalves, J.L., Lopes, R.C., Oliveira, D.B., Costa, S.S., Miranda, M.M., Romanos, M.T., Santos, N.S. and Wigg, M.D. (2005). In vitro anti-rotavirus activity of some medicinal plants used in Brazil against diarrhea. J. Ethnopharmacol., 99:403-7.

16. Groschner, K., Holzmann, S. and Kukovetz, W.R. (1986). Lack of second messenger function of cyclic GMP in acetylcholine-induced negative inotropism. J. Cardiovasc. Pharmacol., 8:1154-7.

17. Kan, H., Ruan, Y. and Malik, K.U. (1996). Localization and characterization of the subtypes(s) of muscarinic receptor involved in prostacyclin synthesis in rabbit heart. J. Pharmacol. Exp. Ther., 276: 934-941.

18. Kamtchouing, P., Sokeng, S.D., Moundipa, P.F., Watcho, P., Jatsa, H.B. and Lontsi, D. (1998). Protective role of Anacardium occidentale extract against streptozotocin-induced diabetes in rats. J. Ethnopharmacol., 62:95-9.

19. Katz, A.M., Repke, D.T. and Cohen, B.R. (1966). Control of the activity of highly purified cardiac actomyosin by $\mathrm{Ca} 2+, \mathrm{Na}+$ and $\mathrm{K}+$. Circ. Res., 19:1062-70.

20. Kerharo, J. and Adams, J.G. (1974). La pharmacopée Sénégalaise traditionnelle, plantes médicinales et toxiques. Paris, Ed.Vigot Frères, $1011 \mathrm{p}$.

21. Kitula, R.A. (2007). Use of medicinal plants for human health in Udzungwa Mountains Forests: a case study of New Dabaga Ulongambi Forest Reserve, Tanzania. J. Ethnobiol. Ethnomed., 3:7.

22. Kohlhardt, M., Bauer, B., Krause, H. and Fleckenstein, A. (1978). New selective inhibitors of the transmembrane Ca++ Conductivity in mammalian miocardial fibers. Studies with the voltage clamp technique. Experientia, 28:288-289.

23. 23. Konan, N.A. and Bacchi, E.M. (2007). Antiulcerogenic effect and acute toxicity of a hydroethanolic extract from the cashew (Anacardium occidentale L.) leaves. J. Ethnopharmacol., 112:237-42.

24. Konan, N.A., Bacchi, E.M., Lincopan, N., Varela, S.D. and Varanda, E.A. (2007). Acute, subacute toxicity and genotoxic effect of a hydroethanolic extract of the cashew (Anacardium occidentale L.). J. Ethnopharmacol., 110:30-8.

25. Kossouoh, C., Moudachirou, M., Adjakidje, V., Chalchat, J.C. and Figueredo, G. (2008). Essential Oil Chemical Composition of Anacardium occidentale L. leaves from Benin. The Journal of essential oil research, 20:5-9.

26. Kudi, A.C., Umoh, J.U., Eduvie, L.O. and Gefu, J. (1999). Screening of some Nigerian medicinal plants for antibacterial activity. J. Ethnopharmacol., 67:225-8.

27. Langer, G.A. (1965). Calcium exchange in dog ventricular muscle: relation to frequency of contraction and maintenance of contractility. Circulation Res., 17:78-89.

28. Laughlin, S.B. (2001). Energy as a constraint on the coding and processing of sensory information. Curr. Opin. Neurobiol., 11:475-80.

29. Lepesckin, E., Surawicz, B., Herrlich, H.C. and Hoffman, B.F. (1957). Correlation between the electrocardiogram and the transmembranaire action potential in potassium and calcium deficiency of mammalian heart. Circulation, 16:906-907.

30. Levine, R.R., Birdsall, N.J.M. and Nathanson, N.M., editors (1999). Proceedings of the Eight International Symposium on Subtypes of Muscarinic Receptors. Life Sci., 64: 355-593.

31. Levine, R.R., Birdsall, N.J.M. and Nathanson, N.M., editors (2001). Proceedings of the Ninth International Symposium on Subtypes of Muscarinic Receptors. Life Sci., 68: 2449-2642.

32. Lüttgau, H.C. and Niedergerke, R. (1958). The antagonism between $\mathrm{Ca}++$ and $\mathrm{Na}+$ ions on the frog's heart. J. Physiol. London, 143:486-505.

33. Molnár, Z., Petheo, G.L., Fülöp, C. and Spät, A. (2003). Effects of osmotic changes on the chemoreceptor cell of rat carotid body. J. Physiol., 546:471-81.

34. Njoroge, G.N. and Bussmann, R.W. (2006). Diversity and utilization of antimalarial ethnophytotherapeutic remedies among the Kikuyus (Central Kenya). J. Ethnobiol. Ethnomed., 2:8.

35. Piétri-Rouxel, F., Gentil, C., Vassilopoulos, S., Baas, D., Mouisel, E., Ferry, A., Vignaud, A., Hourdé, C., Marty, I., Schaeffer, L., Voit, T. and Garcia, L. (2010). DHPR alpha1S subunit controls skeletal muscle mass and morphogenesis. EMBO J., 29:643-54.

36. Prokopczuk, A., Pytkowski, B. and Lewartowski, B. (1981). Effect of acetylcholine on calcium efflux from atrial myocardium. Eur. J. Pharmacol., 70:1-6.

37. Romero, M., Sánchez, I. and Pujol, M.D. (2003). New advances in the field of calcium channel antagonists: cardiovascular effects and structure-activity relationships. Curr. Med. Chem. Cardiovasc. Hematol. Agents, 1:113-41.

38. Rosskopf, D., Schürks, M., Rimmbach, C. and Schäfers, R. (2007). Genetics of arterial hypertension and hypotension. Naunyn Schmiedebergs Arch. Pharmacol., 374: 429-69. 
39. Scheiner-Bobis, G. (2002). The sodium pump. Its molecular properties and mechanics of ion transport. Eur. J. Biochem., 269:2424-33.

40. Seedat, Y.K. (2001). The limits of antihypertensive therapy--lessons from Third World to First. Cardiovasc. J. S. Afr., 12: $94-100$.

41. Sharma, M. and Majumdar, P.K. (2009). Occupational lifestyle diseases: An emerging issue. Indian J. Occup. Environ. Med., 13:109-12.

42. Shenkman, B.S. and Nemirovskaia, T.L. (2009). Role of calcium-dependent mechanisms in the development of atrophy in postural muscle deprived of gravitational loading. Aviakosm Ekolog Med., 43:12-20.

43. Suresh, V. and Asha, V.V. (2008). Preventive effect of ethanol extract of Phyllanthus rheedii Wight. on Dgalactosamine induced hepatic damage in Wistar rats. J. Ethnopharmacol., 116:447-53.

44. Taylor, L.N.D. (2005). The Healing Power of Rainforest Herbs: A Guide to Understanding and Using Herbal Medicinals. Square One Publishers. Garden City Park, p. 535.

45. Tédong, L., Dimo, T., Dzeufiet, P.D., Asongalem, A.E., Sokeng, D.S., Callard, P., Flejou, J.F. and Kamtchouing, P. (2006). Antihyperglycemic and renal protective activities of Anacardium occidentale (Anacardiaceae) leaves in streptozotocin-induced diabetes in rats. Afr. J. Trad. CAM, 3: 23-35.

46. Tédong, L., Dzeufiet, P.D., Dimo, T., Asongalem, E.A., Sokeng, S.N., Flejou, J.F., Callard, P. and Kamtchouing, P. (2007). Acute and subchronic toxicity of Anacardium occidentale Linn (Anacardiaceae) leaves hexane extract in mice. Afr. J. Trad. CAM, 4:140-7.

47. Verrijk, R., Pijnenburg, R.M.M., Vanroptj, H.H., Wehe, R.J. and Porsius, A. (1990). Cellular mechanism in excitationcontraction coupling. Pharmazie, 45:818-23.

48. Wang, Y. and Wang, D.H. (2007). Neural control of blood pressure: focusing on capsaicin-sensitive sensory nerves. Cardiovasc. Hematol. Disord. Drug Targets, 7:37-46.

49. Wang, Z., Shi, H. and Wang, H. (2004). Functional M3 muscarinic acetylcholine receptors in mammalian hearts. Br. J. Pharmacol., 142:395-408.

50. Webb, J.L. and Hollander, P.B. (1956). The action of acetylcholine and epinephrine on the cellular membrane potentials and contractility of rat atrium. Circulat. Res., 4:332-336.

51. Wettwer, E. and Ravens, U. (1991). Spontaneous activity of sodium loaded guinea-pig cardiac myocystes: contribution of $\mathrm{Na}+\mathrm{Ca}++$ exchange. Archives Internationales de physiologie et de biochimie, 49:49-59. 